Abstracta Iranica Abstracta Iranica

Revue bibliographique pour le domaine irano-aryen

Volume 42-43 | 2021

Comptes rendus des publications de 2019-2020

\title{
Li Tang, Dietmar W. Winkler (eds.). Artifact, Text, Context: Studies on Syriac Christianity in China and Central Asia
}

Christelle Jullien

\section{(2) OpenEdition \\ Journals}

Édition électronique

URL : https://journals.openedition.org/abstractairanica/54181

DOI : 10.4000/abstractairanica.54181

ISSN : 1961-960X

Éditeur :

CNRS (UMR 7528 Mondes iraniens et indiens), Éditions de l'IFRI

Référence électronique

Christelle Jullien, « Li Tang, Dietmar W. Winkler (eds.). Artifact, Text, Context: Studies on Syriac

Christianity in China and Central Asia », Abstracta Iranica [En ligne], Volume 42-43 | 2021, document 29,

mis en ligne le 30 décembre 2021, consulté le 15 décembre 2022. URL : http://

journals.openedition.org/abstractairanica/54181; DOI : https://doi.org/10.4000/abstractairanica 54181

Ce document a été généré automatiquement le 15 décembre 2022.

Tous droits réservés 


\section{Li Tang, Dietmar W. Winkler (eds.). Artifact, Text, Context: Studies on Syriac Christianity in China and Central Asia}

Christelle Jullien

\section{RÉFÉRENCE}

Li Tang, Dietmar W. Winkler (eds.). Artifact, Text, Context: Studies on Syriac Christianity in China and Central Asia. Zürich: LIT Verlag, 2020, 275 p. ISBN: 9783643911957. (Orientalia Patristica - CEcumenica 17)

1 L'objectif des éditeurs de ce volume collectif est de faire le point sur les recherches récentes relatives au développement du christianisme en Chine et en Asie Centrale. Ce livre est le cinquième d'une série consacrée à ce sujet, dont les premières conclusions sont toujours présentées lors d'une « International Conference on Syriac Christianity in China and Central Asia ». Les contributions réunies ici, dans un spectre chronologique très large (VII ${ }^{\mathrm{e}}$ XVIII ${ }^{\mathrm{e}}$ siècles), sont ainsi le fruit du $5^{\mathrm{e}}$ colloque tenu à Salzbourg en juin 2016.

2 Elles ont trait pour partie à des discussions terminologiques, à l'étude de concepts spécifiques, de noms propres ou de toponymes:

M. Dickens, "Tarsā: Persian and Central Asian Christians in Extant Literature” (p. 9-42) ;

R. Todd Godwin, "Da Qin, Tajiks, and Their Doctors - East Syrian Scientists across the Courts of Early Medieval Persia, China and Tibet" (p. 43-60);

6 Z.-L. Layec, "Concepts In-Between: The Meaning of "Seng" and "Shoujie" in the Early Jingjiao Documents" (p. 83-94); 
7 S. Muto, “The Term 'Three-One' (Trinity) in Jingjiao in Comparison with That in Taoist Religion" (p. 95-112).

Plusieurs études textuelles avec traductions sont données, avec de nouvelles interprétations, qui permettent de mieux pénétrer la vie religieuse (spécialement les pratiques liturgiques) et sociale des communautés de Chine et d'Asie Centrale : N. Sims-Williams, "The Sogdian "Book of Life" Reconsidered" (p. 113-120) : un texte chrétien en sogdien qu'il suppose être une prière sur amulette ;

Li Tang, "The Liturgical Language of the Church of the East" (p. 121-136) : étude à partir de plusieurs manuscrits chrétiens de Dunhuang et d'inscriptions funéraires de la période Yuan (1271-1368);

11 M. Nicolini-Zani, “The Latin Translation of the Xi'an Stele by the Franciscan Carlo da Castorano (1741)" (p. 137-160) : étude sur la réception du texte par les Latins au XVIII ${ }^{\mathrm{e}}$ siècle et sa transmission ;

G. Thompson, “The Structure of the Xi'an Stele” (p. 161-190).

13 D'autres contributions ont trait à la culture matérielle des chrétiens syriaques et à des analyses picturales ou épigraphiques sur supports: inscriptions funéraires du Kirghizistan (L. Tang), peinture sur soie retrouvée à Dunhuang (L. Tang), croix en bronze de la même provenance (R. Kydd), gravures en motifs de lotus sur les tombes de Yuan (Chine, A. J. Chen) :

Tang, "A Christian Tombstone with Syriac Inscription from Kyrgyzstan (AD 1288/9) Now Kept in the British Museum" (p. 229-232);

15 L. Tang, "Christian or Buddhist? An Exposition of a Silk Painting from Dunhuang, China" (p. 233-244); and English Translation" (p. 213-228). Sur le personnage, signalons la parution en 2020 de l'édition anglaise de l'Histoire: P. G. Borbone, History of Mar Yahballaha and Rabban Sauma: Edited, Translated, and Annotated, traduction par L. E. Parodi à Hambourg: Tredition.

21 Les éditeurs ont fourni un index général utile (p. 273-275). L'ouvrage donne un aperçu lumineux des multiples facettes de la culture et des sociétés chrétiennes de chine et d'Asie Centrale, et répond parfaitement à sa finalité première de les faire connaître du public scientifique. 


\section{AUTEURS}

CHRISTELLE JULLIEN

CNRS, CeRMI, Paris 